(c) 2020

\title{
New morphotype of vegetable corn obtained by the method of experimental mutagenesis
}

\author{
Kulish 0. ${ }^{1}$, Parii M. ${ }^{2}$ \\ Limited Liability Company «All-Ukrainian Scientific Institute of Plant Selection (AUSIPS)» 30 Vasylkivska Str., \\ Kyiv, 03022, Ukraine \\ e-mail: ${ }^{1}$ olyakulish@ukr.net, ${ }^{2}$ pariimyroslav@gmail.com
}

Goal. To obtain genetic mutations using strong chemical mutagens, which have a broad spectrum of action (sodium azide (NaN3) and 5-bromuracil (5BrUra)), with the aim to involve in the selection process; to improve existing and create new high-yielding hybrids of vegetable corn with improved qualities. Methods. Analysis of literature sources, use of strong chemical mutagens, instrumental and statistical. Results. It was established that $5 \mathrm{BrUra}$ can be used as a chemical mutagen on corn plants, and point mutations, which are formed under the influence of that mutagen, are a valuable genetic material in selection practice. A new promising genotype of vegetable corn was obtained. According to the results of comparative evaluation of the phenotypes of the obtained mutant form and the studied collection samples, their significant differences were established. The branching of the obtained form of plants occurs from the base of the rod to the apex, while for known mutant forms - partially from the base to the middle of the rod, or the rod does not branch at all, and several lateral branches are formed. Conclusions. The possibility of using 5-bromuracil as a chemical mutagen on plants has been established. Point mutations, which are manifested under the influence of this mutagen, are valuable genetic material in selection practice. According to the results of comparative evaluation of the obtained mutant forms with collectible samples, it was found that the phenotype of the studied forms have significant differences. A new form of vegetable corn was obtained on the basis of cob branching, which is promising for further research and introduction into production as a new generation of baby corn.

Key words: chemical mutagen, sodium azide $\left(\mathrm{NaN}_{3}\right)$, 5-bromuracil (5BrUra), mutations ra $\mathrm{r}_{1} \mathrm{ra}_{2}, \mathrm{ra}_{3}$. DOI: https://doi.org/10.31073/agrovisnyk202010-06

Vegetable (sweet) corn is in demand in Ukraine and is characterized by high yields; its cobs have excellent taste and nutritional properties. Vegetable corn first entered the world market in the late XVIII - early XIX centuries in the United States of America. Since then, for 100 years, there have been only 12 varieties of this culture in the world. Sweet corn is a valuable food product that has a unique composition of easily digestible carbohydrates: fructose, sucrose, glucose, maltose, raffinose; contains $12-15 \%$ of starch, about $3 \%$ of protein, including essential amino acids lysine and tryptophan, $1 \%$ of fats, $C, B_{1}, B_{2}$, PP vitamins, as well as mineral salts containing $\mathrm{Ca}, \mathrm{K}, \mathrm{Mg}, \mathrm{Fe}, \mathrm{Na}, \mathrm{P}, \mathrm{Cl}$ and $\mathrm{S}$. In 2015, 67 varieties of vegetable corn were included in the Register of varieties allowed for distribution in Ukraine [1].

Analysis of recent research and publications. Polymorphism of sweet corn is not genetically diverse enough, so artificial mutagenesis is used in breeding programs to expand it. The source of genetic diversity of corn are mutations that, in turn, are the original (starting) material in breeding of this crop. Stadler used first radiation to obtain artificial mutations in corn in the 30s of last century, and Rapoport and Auerbach discovered the existence of powerful chemical mutagens in the late 1940s [2, 3]. Among the modern approaches using artificial mutagenesis are Tilling, CRISPR/cas and insertional mutagenesis. Tilling is a method of molecular biology that allows to identify targeted mutations in a particular gene. Tilling was first used on the model object Arabidopsis thaliana in 2000. Since then, it has been used as a method of reverse genetics for other organisms (such as corn, wheat, rice, soybeans, tomatoes and lettuce). This method combines a standard effective mutagenesis method with the chemical mutagen ethyl methanesulfonate (EMS) with a sensitive DNA screening method that identifies one baseline mutation (so-called point mutations) in the target gene [4-6].

It is known that many different chemical mutagens are used for mutagenesis of crops. The chemical mutagen sodium azide $\left(\mathrm{NaN}_{3}\right)$ causes persistent mutations in the DNA sequence of the plant genome [7].

The classic mutagen 5-bromuracil (modified thymine, 5BrUra) has been used for more than half a century to obtain mutants in bacteria $[3,5,6,8-10]$, but there is no information in the available scientific data on the use of 5-bromuracil in plants. Numerous studies have shown experimentally that $5 \mathrm{BrU}$ ra intensely causes point mutations, in particular, transitions of inclusion and replication in bacteriophages, bacteria and some higher organisms [3, 5, 6, 8-11]. In most cases, these are the transitions guanine-cytosine (Gua.Cyt) $\rightarrow$ adenine-thymine (Ade-Thy), but this pattern has many exceptions. Usually 5BrUra is incorporated into DNA randomly in small amounts, but in some cases it can almost completely replace Thy. However, the physicochemical mechanisms of $5 \mathrm{BrUra}$ mutagenic action remain insufficiently studied [11-16]. In particular, there is no universal hypothesis that would quantitatively explain both the origin of inclusion errors and replication errors from a physicochemical standpoint.

The purpose of research. The aim of the study was to obtain genetic mutations using strong chemical mutagens that have a wide spectrum of action - sodium azide $\left(\mathrm{NaN}_{3}\right)$ and 5 -bromuracil ( $\left.5 \mathrm{BrUra}\right)$, to be involved 
in the breeding process; to improve the existing and to create the new high-yielding hybrids of sweet corn with improved qualities.

Materials and methods of research. In our studies we used the corn line PYA-3 (parental component of hybrids from the All-Ukrainian Scientific Institute of Breeding) and samples 727 G, 708 A, 308 E, 725 A, 725 B from the collection of Maize Genetics Cooperation Stock Center [1].

As a mutagenic factor was used 5-bromuracil (5BrUra) in concentrations: 0.0191, 0.0955, 0.191, 0.573 and $1.91 \mathrm{~g} / \mathrm{l}$, respectively; and sodium azide $\left(\mathrm{NaN}_{3}\right)-1.95,2.6$ and $3.25 \mathrm{~g} / \mathrm{l}$ [17].

Corn grains were germinated at a temperature of $24^{\circ} \mathrm{C}$ on moistened filter paper until the first roots up to $0.4 \mathrm{~cm}$ long. Then eight samples of 100 seeds were taken and soaked in solutions of chemical mutagens $5 \mathrm{BrUra}$ and $\mathrm{NaN}_{3}$ in the above concentrations. Exposure time was two hours. The PYA-3 line, the grains of that were not treated with mutagens, was used as a control [17].

Obtained in generations $M_{0}, M_{1}$ and $M_{2}$ plants self-pollinated. The 272 families of the $M_{1}$ generation were sown. The number of branches on the panicle and cobs, the length of the branches on the cobs, the productivity of the cob and individual branches were determined for the mutant form. Statistical analyses of obtained experimental data were carried out using Microsoft Excel $(p>0.05)$.

Results and discussion. A decrease in seed germination was observed in the $M_{0}$ generation. Seed germination decreased with increasing concentration of mutagenic factor. Phenotypic changes of plants mutations of maize plants (curved stem, dwarfism, lack of generative organs) were detected in all variants during subsequent observations of their development (Table 1).

\section{Phenotypic effect in Mo generation}

\begin{tabular}{|l|l|l|l|l|l|l|}
\hline \multirow{3}{*}{ Mutagen } & $\begin{array}{l}\text { Concentra } \\
\text { tion, g/l }\end{array}$ & $\begin{array}{l}\text { Number of } \\
\text { treated grains }\end{array}$ & $\begin{array}{l}\text { Number of } \\
\text { similar } \\
\text { plants }\end{array}$ & $\begin{array}{l}\text { Number of } \\
\text { plants without } \\
\text { phenotypic } \\
\text { changes }\end{array}$ & $\begin{array}{l}\text { Number of } \\
\text { plants with } \\
\text { changes in } \\
\text { phenotype }\end{array}$ & $\begin{array}{l}\text { Phenotypic } \\
\text { effect, \% }\end{array}$ \\
\hline \multirow{3}{*}{$\mathrm{NaN}_{3}$} & 1.95 & 100 & 76 & 69 & 7 & 9.2 \\
\cline { 2 - 7 } & 2.6 & 100 & 73 & 63 & 10 & 13.7 \\
\cline { 2 - 7 } & 3.25 & 100 & 69 & 57 & 12 & 17.4 \\
\hline \multirow{5}{*}{5 BrUra } & 0.0191 & 100 & 58 & 22 & 36 & 62.1 \\
\cline { 2 - 7 } & 0.0955 & 100 & 52 & 35 & 17 & 32.7 \\
\cline { 2 - 7 } & 0.191 & 100 & 34 & 13 & 21 & 61.8 \\
\cline { 2 - 7 } & 0.573 & 100 & 25 & 5 & 14 & 60.9 \\
\cline { 2 - 7 } & 1.91 & 100 & 23 & 9 & & \\
\hline
\end{tabular}
$13.4 \%$.

Frequency of occurrence of phenotypic changes using $5 \mathrm{BrU}$ ra was on the average $59.5 \%$ and $\mathrm{NaN}_{3}-$

The obtained data indicated that the phenotypic effect of the 5BrUra mutagen was higher compared to the effect observed with $\mathrm{NaN}_{3}$. The highest level of inhibition was found in the case of $5 \mathrm{BrUra}$ at a concentration of $1.91 \mathrm{~g} / \mathrm{l}$. Plants were characterized by developmental delays with subsequent extinction. This effect was not observed among plants treated with $\mathrm{NaN}_{3}$. Thus, we can assume that the used concentrations of this chemical factor are not lethal, and therefore it is impractically to compare the phenotypic effect.

The frequency of mutations was determined in the $M_{1}$ generation. Mutations were detected in 42 of 272 families during phenotypic observations. Of the 84 families treated with $5 \mathrm{BrU}$ ra, only 5 had mutations, and of the 198 families treated with $\mathrm{NaN}_{3}, 36$ had mutant forms (Table 2).

\section{Frequency of mutations in the $M_{1}$ generation}

\begin{tabular}{|c|c|c|c|c|c|}
\hline Mutagen & Concentration, g/l & $\begin{array}{l}\text { Number of } \\
\text { families }\end{array}$ & $\begin{array}{l}\text { Number of } \\
\text { families without } \\
\text { mutations }\end{array}$ & $\begin{array}{l}\text { Number of } \\
\text { mutant } \\
\text { families }\end{array}$ & $\begin{array}{l}\text { Frequency of } \\
\text { mutations, \% }\end{array}$ \\
\hline \multirow{3}{*}{$\mathrm{NaN}_{3}$} & 1.95 & 81 & 69 & 12 & 14.8 \\
\hline & 2.6 & 62 & 49 & 13 & 20.9 \\
\hline & 3.25 & 55 & 44 & 11 & 20 \\
\hline \multicolumn{2}{|l|}{ Total } & 198 & 162 & 36 & 18.2 \\
\hline \multirow{5}{*}{ 5BrUra } & 0.0191 & 22 & 18 & 4 & 18.2 \\
\hline & 0.0955 & 35 & 34 & 1 & 2.9 \\
\hline & 0.191 & 13 & 13 & 0 & 0 \\
\hline & 0.573 & 5 & 5 & 0 & 0 \\
\hline & 1.91 & 9 & 9 & 0 & 0 \\
\hline \multicolumn{2}{|l|}{ Total } & 84 & 79 & 5 & 6 \\
\hline
\end{tabular}

The frequency of mutations in the $\mathrm{M}_{1}$ generation for families treated with $\mathrm{BrU}$ was $6 \%$, and with the use of $\mathrm{NaN}_{3}-18.2 \%$ (Table 2). 
Representatives of 272 studied families had the following mutations: plant coloration - albinos, anthocyan coloration of stems and leaves; stem shape - curved stem in 2-3 internodes, shortened internodes; shape of leaf - linear leaves up to $2 \mathrm{~cm}$ wide, fused and twisted leaves; structure of inflorescences - branched panicle, branching of a cob; absence of male generative organs - grained panicle.

Among the obtained mutant forms of corn for practical application and introduction into production, in our opinion, the most promising is the mutation of branching of the cob and panicle (Fig. 1). The obtained mutant form of corn is phenotypically similar to the phenotypic manifestation of the recessive ramosa gene (ra). There are three genes for branching of the cob: $r a_{1}, r a_{2}$ and $r a_{3}$. The homozygote for the ra gene has a branched cob that usually does not form grains well. The panicle is characterized by a large number of twigs that extend from the central axis almost perpendicularly. Homozygotes for the $\mathrm{ra}_{2}$ gene have only a branched cob apex, and its base remains intact. Cobs end often in twigs with anthers. The panicle differs from the normal panicle and from the one of homozygotes ra ${ }_{1}$. Cobs of $r a_{3}$ homozygotes form small additional well-grained cobs that grow from the base of the main rod [2].

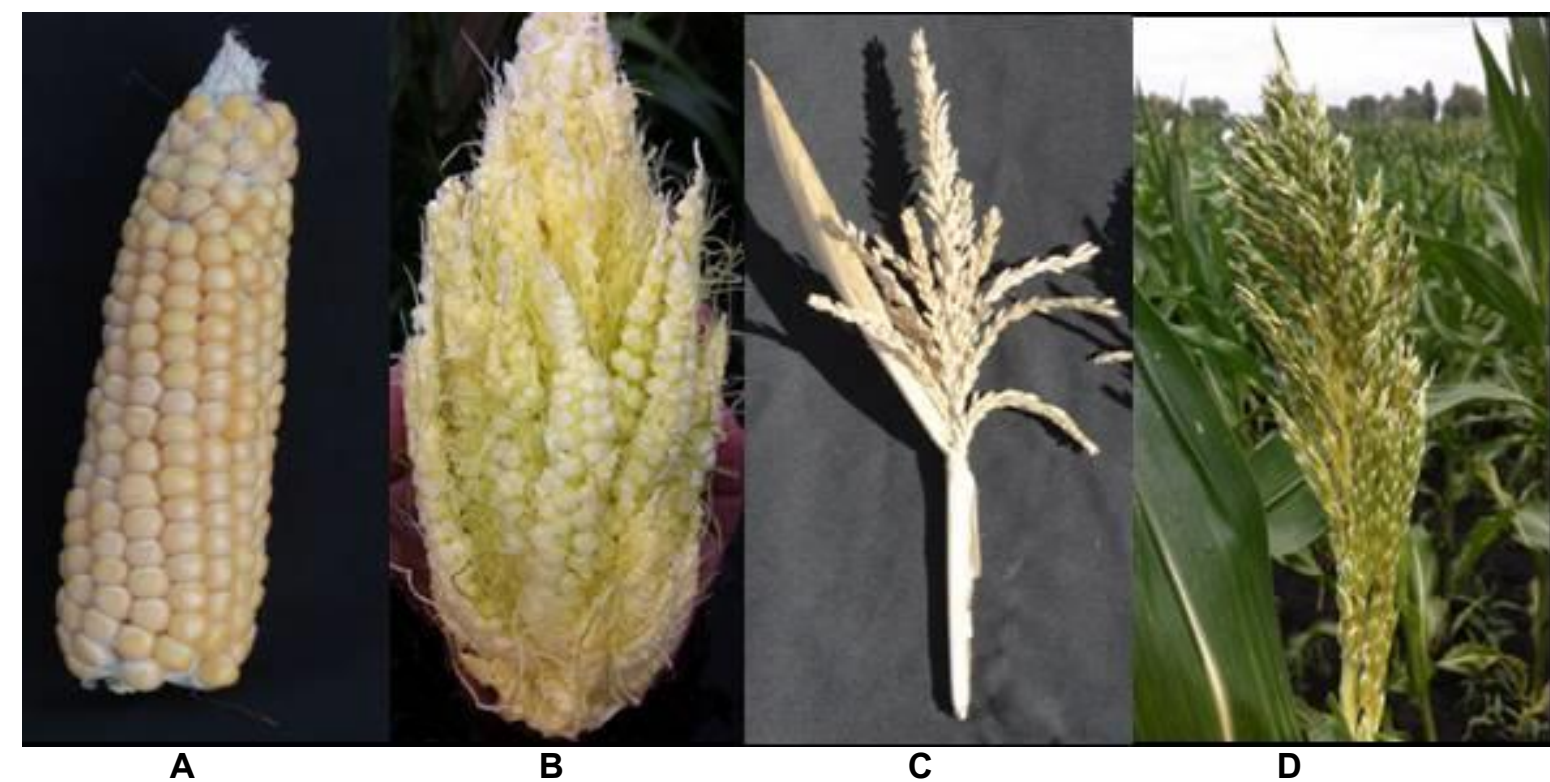

Fig. 1. Phenotypic manifestation of the mutant line: A - cob of siliceous corn, B - branched cob of mutant form, C - panicle of siliceous corn, D-branched panicle.

No manifestation of a recessive gene with a phenotype of cob shape change in the $\mathrm{M}_{0}$ generation was detected. The appearance of corn forms with branched panicles and branched cobs was observed in the $M_{1}$ generation, the splitting of that corresponded to 3:1. When self-pollinating such mutant forms, the offspring fully corresponded to the parental forms; it led to the conclusion that such phenotypic changes are genetically fixed. So, all plants of the $\mathrm{M}_{2}$ generation had branched cobs and panicles. Based on the obtained data, such a mutant form can be included in the breeding process and used as a potential donor of this phenotypic trait.

The obtained mutant line was characterized by a complex of economically valuable features; its comparative assessment with samples from the collection of the Maize Genetics Cooperation Stock Center (MGCSC), as well as with siliceous corn was conducted. Characteristics of the mutant line: the length of the rod varied from 11 to $12.5 \mathrm{~cm}$. Cobs consisted of an average of 50-53 branches, among them 30-36 were productive and formed full-fledged grains. Each individual branch may have second-order branches. The branches on the rod differed in size, so they were classified into four types (Table 3, Fig. 2A). The mutant line exceeded siliceous corn in the number of baby corn cobs on the plant. The 3-4 cobs are formed on a siliceous corn plant, while a mutant line can form two branched cobs with a total number of branches of about 100-110 (Fig. 2A).

\section{Types of branches and their productivity}

\begin{tabular}{|l|l|l|l|l|l|}
\hline Type of branch & $\begin{array}{l}\text { Number of } \\
\text { branches, pcs. }\end{array}$ & $\begin{array}{l}\text { Length of } \\
\text { branches, } \\
\text { cm }\end{array}$ & $\begin{array}{l}\text { Number of } \\
\text { grain rows, } \\
\text { pcs. }\end{array}$ & $\begin{array}{l}\text { Number of } \\
\text { grains in a } \\
\text { row, pcs. }\end{array}$ & $\begin{array}{l}\text { Productivity of one } \\
\text { branch, grains per 1 } \\
\text { branch }\end{array}$ \\
\hline Mutant form ra & 2 & 5.5 and $>$ & 4,5 & 17 & 65 \\
\hline Very large & 4 & $5.0-5.5$ & 4 & 12 & 48 \\
\hline Large & 12 & $4.0-5.0$ & 4 & 10 & 36 \\
\hline Medium & 16 & $2.0-4.0$ & 4 & 6 & 24 \\
\hline Small & 17 & $<2.0$ & 2,4 & $1-4$ & 4 \\
\hline Very small &
\end{tabular}




\begin{tabular}{|c|c|c|c|c|c|}
\hline \multicolumn{6}{|c|}{ Carrier line of the ra 1 mutation } \\
\hline Large & 11 & $5.0-5.5$ & 4 & 10 & 40 \\
\hline Medium & 7 & $3.5-4.0$ & $2-4$ & 7 & 35 \\
\hline Small & 16 & $2.0-3.0$ & 2 & 6 & 12 \\
\hline Very small & 39 & $<2.0$ & 1 or 2 & 0 & 0 \\
\hline \multicolumn{6}{|c|}{ Carrier line of the $\mathrm{ra}_{2}$ mutation } \\
\hline Large & 5 & $5.0-5.5$ & 4 & 13 & 52 \\
\hline Medium & 5 & $3.5-4.0$ & 2 & 6 & 12 \\
\hline Small & 6 & $2.0-3.0$ & 1 or 2 & 3 & 4 \\
\hline Very small & 11 & $<2.0$ & 1 or 2 & 1 & 1 \\
\hline \multicolumn{6}{|c|}{ Carrier line of the $\mathrm{ra}_{3}$ mutation } \\
\hline Large & 2 & $5.0-5.5$ & $4-6$ & 12 & 60 \\
\hline Medium & 3 & $3.5-4.0$ & $2-4$ & 9 & 18 \\
\hline Small & 2 & $2.0-3.0$ & 1 or 2 & 5 & 5 \\
\hline Very small & 6 & $<2.0$ & 1 or 2 & 0 & 0 \\
\hline
\end{tabular}

Lines of corn from MGCSC $727 \mathrm{G}, 708 \mathrm{~A}, 308 \mathrm{E}, 725 \mathrm{~A}, 725 \mathrm{~B}$ were assessed for the same morphological parameters. The $727 \mathrm{G}$ and $708 \mathrm{~A}$ lines are carriers of the ra ${ }_{1}$ mutation and have branched cobs and panicles. The rod length averaged $14 \mathrm{~cm}$. The cob was divided into two parts, the lower of which branched and was $8-9 \mathrm{~cm}$ long, and the upper - about $6 \mathrm{~cm}$ and formed a 12-row cob with 11 grains in a row. The grains were siliceous, up to $1 \mathrm{~cm}$ long (about $0.7 \mathrm{~cm}$ in diameter). The lower part of the cob formed up to 73 branches, 34 of them were productive (Table 3, Fig. 2B).

Line $308 \mathrm{E}$ is a carrier of $r a_{2}$ mutations. The shape of its cob differed significantly from ra $\mathrm{A}_{1}$. The carrier line of the $\mathrm{ra}_{2}$ mutation formed a large number of branches that formed chaotically throughout the rod. On the cob tops formed a male organ - the panicle. The cob length was $26 \mathrm{~cm}, 40$ or more branches $2.0-6.5 \mathrm{~cm}$ long were formed on it (Table 3, Fig. 2C). 

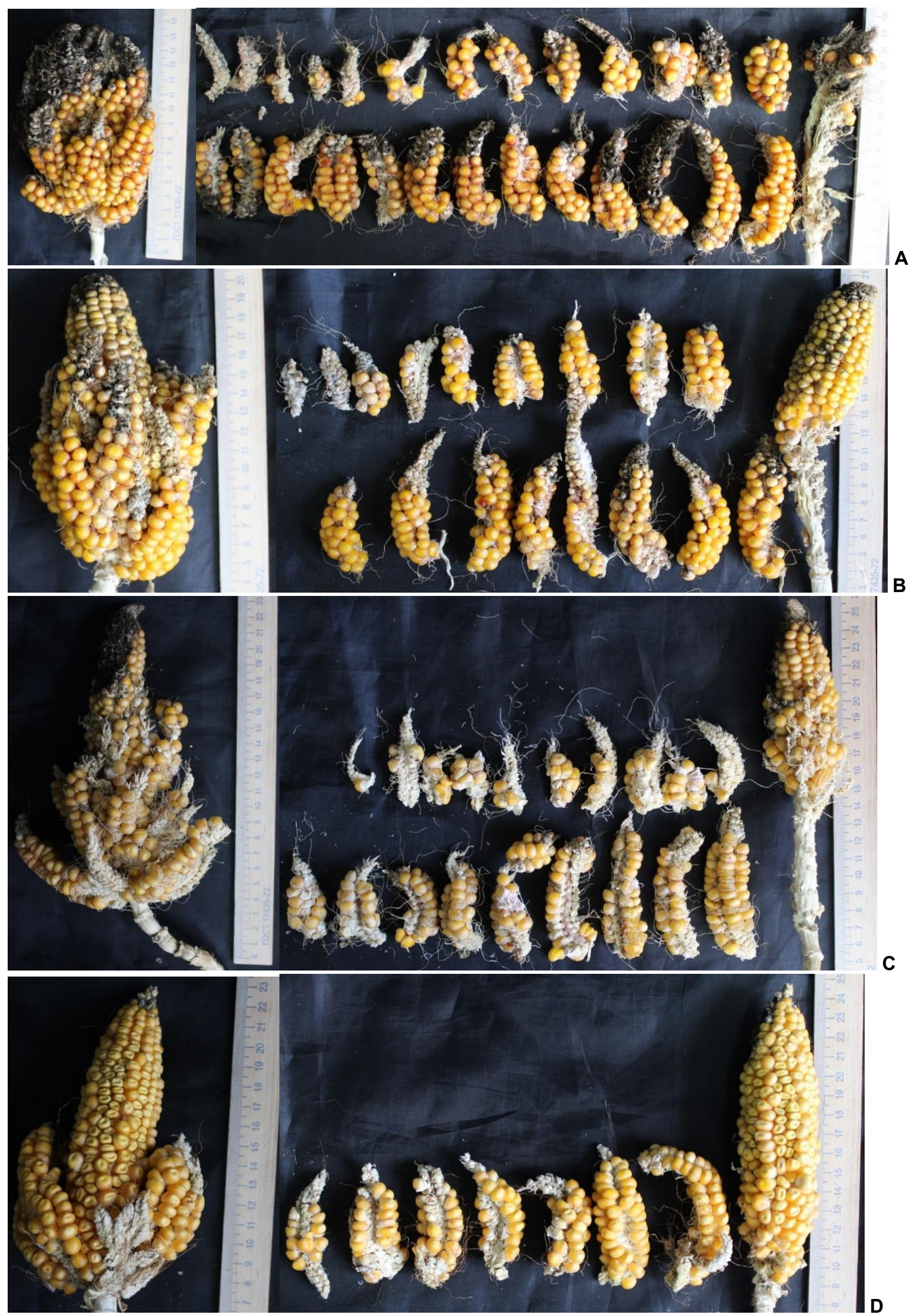

Fig. 2. Corn cobs with mutations: $A-r a, B-r a_{1}, C-r a_{2}, D-r a_{3}$ 
Line $725 \mathrm{~A}$ is a carrier of $\mathrm{ra}_{3}$ mutation; by the shape of the cob and the type of branching, it is characterized by the formation of a small number of branches that are formed from the base of the rod and are well grained. The number of branches varied from 8 to 12 . The cob had 12-14 grain rows. The cob length reached $23 \mathrm{~cm}$, the grains were toothed-siliceous (Table 3, Fig. 2D).

The male organ - the panicle, in all studied forms was characterized by its own characteristics. The number of branches of the first and second orders on the panicle differed significantly in all studied forms (Table 4, Fig. 3).

\section{The number of branches on the panicle}

\begin{tabular}{|l|l|l|l|l|l|}
\hline \multirow{2}{*}{ Type of branch } & PYA-3 & ra - PYA-3 & \multicolumn{4}{|c|}{ The carrier line of the gene mutation } \\
\cline { 4 - 6 } & control & treated with 5BrUra & $r a_{1}$ & $r a_{2}$ & $r a_{3}$ \\
\hline First order & 11 & 40 & 47 & 52 & 49 \\
\hline Second order & 3 & 15 & 8 & 16 & 14 \\
\hline
\end{tabular}

Donors of genetic traits were needed to create and implement new hybrids of sweet corn. We created a collection of vegetable corn and used chemical mutagenesis to find and introduce donors into the breeding process. As a result of chemical mutagenesis, we have identified a number of mutant forms, among which the most promising for industrial use was the mutant form with a branched cob.

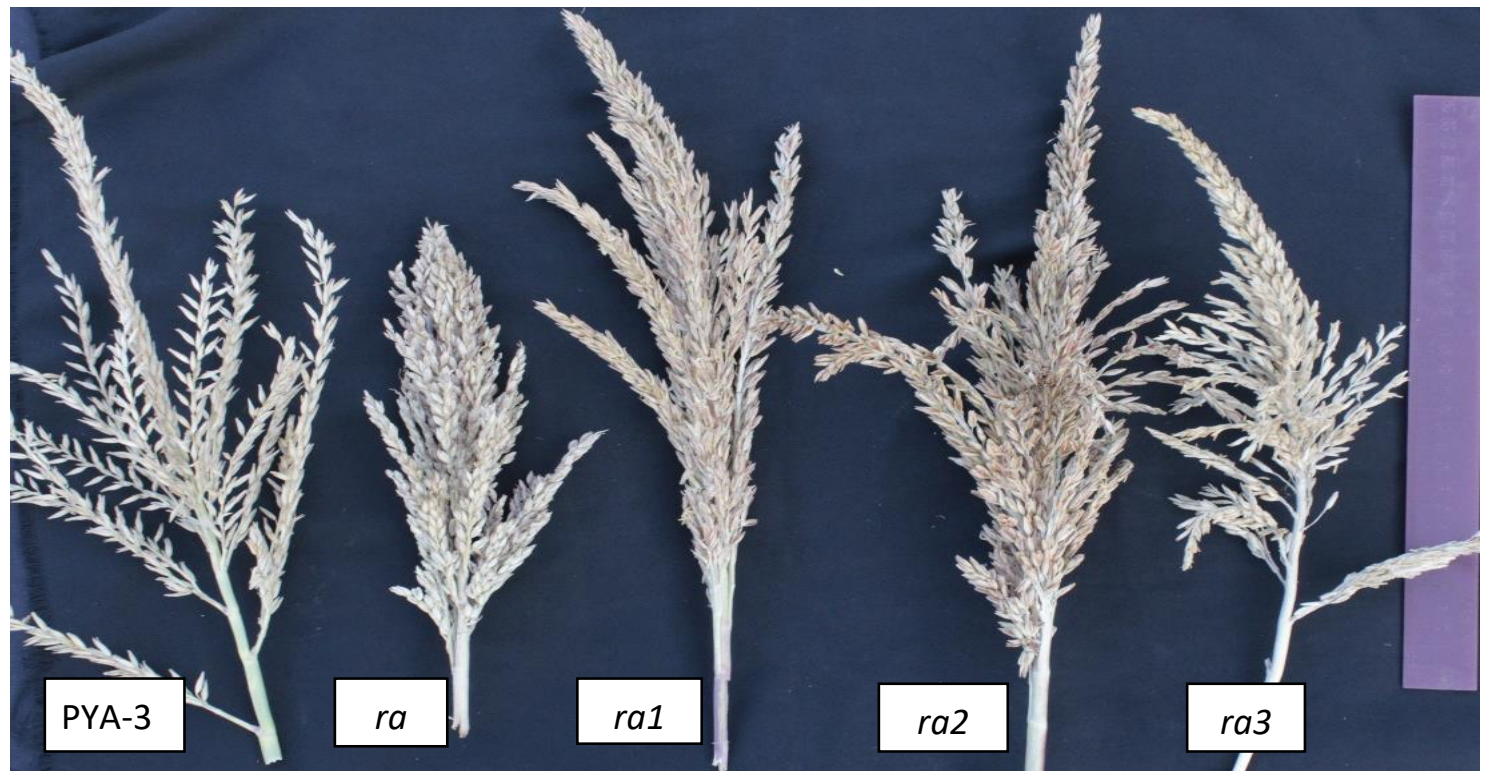

Fig. 3. The shape of the panicles of the studied lines: PYA-3 - control, ra - PYA-3 treated with $5 B r U r a, r a_{1}$ - carrier line of the ra ${ }_{1}$ mutation, ra $\mathrm{ra}_{2}$ - carrier line of the ra $\mathrm{C}_{2}$ mutation, $\mathrm{ra}_{3}$ - carrier line of the ra $\mathrm{ratation}_{3}$

When comparing the carrier lines of mutations $r a_{1}, r a_{2}$ and $r a_{3}$ from the collection of MGCSC with the mutant form, it was found that all the studied samples differed in the shape of the cob. The mutant form is most similar to the carrier line of the ra ${ }_{1}$ mutation. These two lines differ in the type of branching of the cob. In contrast to the mutant form, in which the cob branches along the entire length of the rod, the carrier line of the mutation $r \mathrm{a}_{1}$ is characterized by partial branching of the cob - the head branches to the middle of the rod.

\section{Conclusions}

A new promising for breeding practice genotype of sweet corn was obtained. 5-Bromuracil can be used as a chemical mutagen on plants, and the point mutations manifesting by the action of this mutagen are valuable genetic material in breeding practice. According to the results of comparative assessment of the obtained mutant form with collection samples, it was found that the phenotype of the studied forms have significant differences. Thus, we have obtained a new form of sweet corn on the basis of cob branching; it is promising for further research and introduction into production as a new generation of baby corn.

\section{References}

1. Maize Genetics and Genomics Database. URL: http://archive. maizegdb.org

2. Miku, V.E. (1981). Geneticheskiye issledovaniya kukuruzy [Genetic research in corn]. Monograph. Kishinev. [In Russian].

3. Oladosu, Yu., Rafii, M.Y., Norhani, A., Ghazali, H., Ramli, A., Rahim, H.A., Gous, M., \& Magaji, U. (2016). Principle and application of plant mutagenesis in crop improvement. Biotechnology \& Biotechnological Equipment, 30(1), 1-16. doi: 10.1080/13102818.2015.1087333 
4. Henikoff, S., Till, B.J., \& Comai, L. (2004). TILLING. Traditional Mutagenesis Meets Functional Genomics. Plant Physiology, 135(2), 630-636. doi: 10.1104/pp.104.041061

5. Mba, C. (2013). Induced mutations unleash the potentials of plant genetic resources for food and agriculture. Agronomy, 3, 200-231. doi: 10.3390/agronomy3010200

6. Lu, X., Liu, J., Ren, W. et al. (2018). Gene-indexed mutations in maize. Mol. Plant., 11, 496-504. doi: 10.1016/j.molp.2017.11.013

7. Olsen, O., Wang, X., \& von Wettstein, D. (1993). Sodium azide mutagenesis: preferential generation of A.T-->G.C transitions in the barley Ant18 gene. PNAS, 90(17), 8043-8047. doi: 10.1073/pnas.90.17.8043

8. Auerbach, Sh. (1978). Problemy mutageneza [Mutagenesis problems]. Monograph. Moscow: Mir. [In Russian].

9. Malyuta, S.S. (Tolstoukhov, A.V. (Ed.)) (2007). Mutahenez. Ekolohichna entsyklopedia: u 3-kh t. [Mutagenesis. Ecological encyclopedia: in 3 volumes]. Vol. 2. Kyiv: TOV Tsentr ekolohichnoi osvity ta informatsii. [In Ukrainian].

10. Tarasov, V.A. (1982). Molekulyarnye mekhanizmy reparatsii i mutageneza [Molecular mechanisms of reparation and mutagenesis]. Monograph. Moscow: Nauka. [In Russian].

11. Hu, X., Li, H., Ding, J., \& Han, S. (2004). Mutagenic mechanism of the A-T to G-C transition induced by 5-bromouracil: anabinitio study. Biochemisrty, 43(21), 6361-6369.

12. Brovarets, O.O., \& Hovorun, D.M. (2009). Novyi fiziko-khimichnyi mekhanizm mutahennoi dii 5bromuratsilu [A new physicochemical mechanism of mutagenic action of 5-bromuracil]. Ukrainica Bioorganica Acta, 2, 19-23. [In Ukrainian].

13. Danilov, V.I., var Mourik, T., Kurita, N., Wakabayashi, H., Tsukamoto, T., \& Hovorun, D.M. (2009). On the mechanism of the mutagenic action of 5-bromouracil: a DFT study of uracil and 5-bromouracil in a water cluster. The Journal of Physical Chemistry A, 113(11), 2233-2235. doi: 10.1021/jp811007j

14. Hanus, M., Kabel, M., Nachtigallov, D., \& Hobza, P. (2005). Mutagenic properties of 5-halogenuracils: correlated quantum chemical ability study. Biochemistry, 44(5), 1701-1707. doi: 10.1021/bi048112g

15. Kurita, N., Danilov, V.I., Anisimov, V.M., Hovorun, D., Nakatsu, T., \& Dedachi, K. (2007). Mechanisms of mutagenic action of 5BrU: quantum mechanical study. J. Mol. Struct. Dyn., 24, 665.

16. Orozco, M., Hernandez, B., \& Luque, F.J. (1998). Tautomerism of 1 methyl derivatives of uracil, thymine, 5 -bromouracil. Is tautomerism the basis for the mutagenicity of 5-bromouridine? The Journal of Physical Chemistry B, 102(26), 5228-5233. doi: 10.1021/jp981005+

17. Kulish, O.Yu., Pogrebliuk, M.V., Kovalchuk, Z.V., Babych, V.O., Symonenko, Yu.V., \& Parii, M.F. (2016). Zastosuvannia metodu eksperymentalnoho mutahenezu dlia ovochevoi kukurudzy [Application of the method of experimental mutagenesis for vegetable corn]. Factors in Experimental Evolution of Organisms, 18, 102-105. http://nbuv.gov.ua/UJRN/feeo_2016_18_23 